\title{
Değirmendere'nin CBS Tabanlı Deprem Risk ve Erişebilirlik Analizi
}

\author{
İsmail Talih GÜVEN ${ }^{1}$, Deniz GERÇEK ${ }^{2}$
}

\section{Öz}

Bu çalışmada, Değirmendere beldesinde, Coğrafi Bilgi Sistemleri (CBS) temelli, depreme yönelik afet yönetimi zarar azaltma amacıyla bir sistem geliştirilmiştir. Geliştirilen sistem için öncelikle bölgede yapılmış olan çalışmalar, 17 Ağustos 1999 depreminde bölgede oluşan zararlar ve sebepleri incelenmiş ve bölgede depremde yapıları etkileyen yerbilimleri verilerine dayanarak risk oranları ve yerbilimleri verilerinin alt kategorilerinin etki oranlarına göre alt risk oranları belirlenmiştir. Bölgenin depreme yönelik tehlike analizinin yapmakta kullanılan bu verilerin CBS ortamında değerlendirilebilmesi için Analitik Hiyerarşik Süreç (AHS) yöntemi ile ağırlıklandırılması yapılmıştır. Analiz birimi olarak 'alan' । esas alan diğer CBS çalışmalardan farklı olarak, tüm veriler, yapı birimlerinin öznitelik değeri olarak CBS ortamına aktarılmıştır. Bölgede yaşayan nüfus ile ilgili demografik bilgiler Nüfus Vatandaşlık Genel Müdürlüğü'nden elde edilmiş ve yine yapılara ait veri olarak CBS ortamına aktarılmıştır.

Sonrasında da CBS ortamında tehlike analizleri yapılarak bölgedeki riskli yapılar ve risk oranları belirlenmiştir. Diğer afet yönetimi çalışmalarından farklı olarak, riskli yapılarda yaşayan nüfus verileri de değerlendirilmiş ve bunlara yönelik önerilerde bulunulmuştur.

Anahtar Kelimeler: Afet Yönetimi, Analitik Hiyerarşik Süreç (AHS), Coğrafi Bilgi Sistemleri (CBS), Tehlike Analizi, Zarar Azaltma.

\section{The GIS-Based Earthquake Risk and Accessibility Analysis of Değirmendere}

\begin{abstract}
A system is developed within Geographical Information Systems (GIS) with the aim of hazard mitigation of earthquakes in Değirmendere for disaster management. Initially, former studies conducted in the region have been examined; the damages during the earthquake on August 17, 1999 and their reasons have been investigated. Regarding the earth sciences data that affect buildings during an earthquake ratios of risk and in relation to degree of affect of sub-categories of these data to buildings during an earthquake have been identified. In order to be able to evaluate the risk analysis of the region for earthquakes within GIS, the weighting of these data have been realized with the method of Analytic Hierarchy Process (AHP). In contrast to other GIS studies which take regions as basic mapping unit, all data have been transferred into GIS medium as a attribute value for building entities.

Demographic information on the residents of the region have been obtained from the General Directorate of Civil Registration and Nationality, and transferred into GIS medium as another value for each building. Afterwards, risk and network analyses have been conducted in GIS Medium, and the buildings under risk and their ratios have been determined. As a contrast to other studies of disaster management, demographic data of the population living in buildings under risk have also been evaluated and suggestions have been made for these cases.
\end{abstract}

Keywords: Disaster Management, Analytic Hierarchy Process (AHP), Geographical Information Systems (GIS), Risk Analysis, Network Analysis, Hazard Mitigation.

\footnotetext{
${ }^{1}$ Kocaeli Üniversitesi, Mimarlık ve Tasarım Fakültesi, Mimarlık Bölümü, Kocaeli.

${ }^{2}$ Kocaeli Üniversitesi, Mimarlık ve Tasarım Fakültesi, Şehir ve Bölge Planlama Bölümü, Kocaeli.

*ilgili yazar / Corresponding author: talihguven@yahoo.com

Gönderim Tarihi: 10.12.2017

Kabul Tarihi: 15.12.2017
} 
Değirmendere'nin CBS Tabanlı Deprem Risk ve Erişebilirlik Analizi

The GIS-Based Earthquake Risk and Accessibility Analysis of Değirmendere

\section{Gíriş}

İnsanlar tarih boyunca doğal olaylarla karşılaşmışlardır. Toplulukların sosyo-ekonomik ve teknolojik gelişmişlik düzeylerine bağlı olarak olaylarla başa çıkmaya biçimleri başarısızlıkla sonuçlandığında, bu doğal olaylar afetlere dönüşmüştür (Acerer, 1999).

Aletsel dönem olarak tanımlanan 1900 'lü yıllardan günümüze kadar Türkiye'de büyüklükleri 5,0-7,9 arasında olan 116 adet deprem meydana gelmiştir (URL-1). Bu rakamlara göre ülkemiz her yıl bir büyük deprem yaşamaktadır. Afetlerin yerini, zamanını ve etki derecesini önceden belirleyebilmek ve tamamen ortadan kaldırmak mümkün değil ise de hazırlıklı olmak ve afetleri minimum zararla atlatmak hedeflenmelidir (Aksaraylı, 2005). Yaşadığımız tüm afet tecrübelerine rağmen, toplum olarak deprem gibi tekrarlanan bir afet karşısında bile zararın azaltılmasına yönelik bir duyarlılık ve hassasiyet gösteremiyoruz. Yaşadığımız depremlerde yaklaşık 600.000 civarında yapı hasar görmüş, 85.000 kişi hayatını kaybetmiş̧ir. Sadece 17 Ağustos depreminde ki maddi kaybın 6 milyar US \$ ila 10 milyar US \$ arası olduğu belirtilmektedir.

Depremler yarattıkları can ve mal kayıplarının yanında bölgesel sorunlara da sebep olmaktadırlar. Deprem sonrası yaşanan ekonomik kayıplar, deprem bölgesindeki fiziksel hasarlar depremi hisseden insanlardaki sosyo-psikolojik tahribatlar ve deprem sonrası yaşanan göçler bunlardan bazılarıdır. Güç koşullarda yarattığımız ekonomik ve sosyal değerler saniyeler içinde kaybedebilmektedir.

Meydana gelen deprem veya diğer afetler karşısında ülke olarak hem can kaybı hem de mal kayıplarımızın oranı çok yüksek olmaktadır. Yaşanan tecrübeler, afet sonrası karışıklık ve zamanında müdahale edememekten kaynaklanan zararların, afet nedeniyle oluşan zararlardan daha fazla olabileceğini göstermiştir (Aksaraylı, 2005). Ülkemizde "Afet Yönetimi" çalışmaları son on yılda hız kazanmakla birlikte, karşılaşılan afetlerde yapılan uygulamalar istenen düzeyden çok uzakta olduğumuzu göstermektedir.

Afet yönetimi ve özellikle zarar azaltma çalışmaları, Coğrafi Bilgi Sistemleri (CBS) gibi veri yönetiminin ve güncellenmesinin yapılabileceği, çok disiplinli sorgulama ve bilgi girişlerinin düzenlenebileceği bir sistemin desteği ile başarıya ulaşacaktır. Herhangi bir zarar azaltma önleminin fayda sağlayabilmesi, onun uygulanabilir olmasına ve söz konusu tehlikeye karşı koruyucu bir işlevinin bulunmasına bağlıdır (Güler, 2008).

Çalışmada, yapıların hasar görebilirliğinin ortaya konduğu ve yapılarda yaşayan kişilerin risklerinin değerlendirildiği, afet öncesi risk yönetimi ve afet sonrası kriz yönetimi için önerilerde bulunan CBS tabanlı bir sistem tasarlanmıştır. Çalışmanın amacı, izlenen yöntem ve veri yönetimi sayesinde Değirmendere'de olası bir deprem karşısında risklerin önceden tespit edilmesi ve tespit edilen risklere karşı alınabilecek önlemleri belirlemektir.

Çalışma sonunda elde edilen yapı üzerindeki risk değerleri demografik dağılım ile birlikte analiz edilerek olası deprem karşısında etkilenecek nüfus belirlenmiştir. Oluşturulan bu sistem sayesinde; olası bir depremin yapılar ve dolayısıyla insana ve topluma vereceği zararın azaltılması, deprem sonrasında da riski yüksek yapılar ve bu yapılarda yaşayan insanlar için ilk müdahale biçimlerinin yönlendirilmesi, bu sayede can kayıplarının azaltılması da amaçlanmaktadır. 
Çalışma, afet öncesi zarar azaltmaya, afet sonrası da milli kaynakları verimli kullanmaya yönelik,

Güvenilir ve güncellenebilir,

Çok disiplinli çalışmalar için uygun bir sistem tasarlamak,

Yerel yönetim ve afet sonrası kriz masaları için kullanılabilir ve yönetilebilir bilgi üretilebilen bir sistem önermektedir.

Çalışmada, afet öncesi yerbilimleri verileri ile deprem riski belirlenerek, zarar azaltmaya yönelik, güncellenebilir, farklı bölgelerde de uygulanabilir bir sistem oluşturulmuştur.

Çalışmada takip edilen yöntem, TÜBITAK tarafından 112M421 no ve "Kocaeli- GölcükDeğirmendere Beldesi Kentsel Afet Risk Yönetimine Dair Tehlike Analizinin Saptanması Projesi" başlıklı proje kapsamında da uygulanmıştır.

\section{2. ÇALIŞMA ALANI}

Kocaeli ili, Gölcük ilçesi, Değirmendere beldesi çalışma alanı olarak seçilmiştir (Şekil 1). Çalışma alanında 7 mahalle, 3456 adet yapı bulunmaktadır. Kuzey Anadolu Fay Zonu'nun kuzey kolunda meydana gelmiş olan, 17 Ağustos 1999 Gölcük Depremi yüzey kırığı çalışma alanının kuzeyinden geçmektedir (Şekil 1).

Kocaeli ili, Gölcük ilçesi, Değirmendere beldesi çalışma alanı olarak seçilmiştir (Şekil 1). Çalışma alanında 7 mahalle, 3456 adet yapı bulunmaktadır. Kuzey Anadolu Fay Zonu'nun kuzey kolunda meydana gelmiş olan, 17 Ağustos 1999 Gölcük Depremi yüzey kırığı çalışma alanının kuzeyinden geçmektedir (Şekil 1).
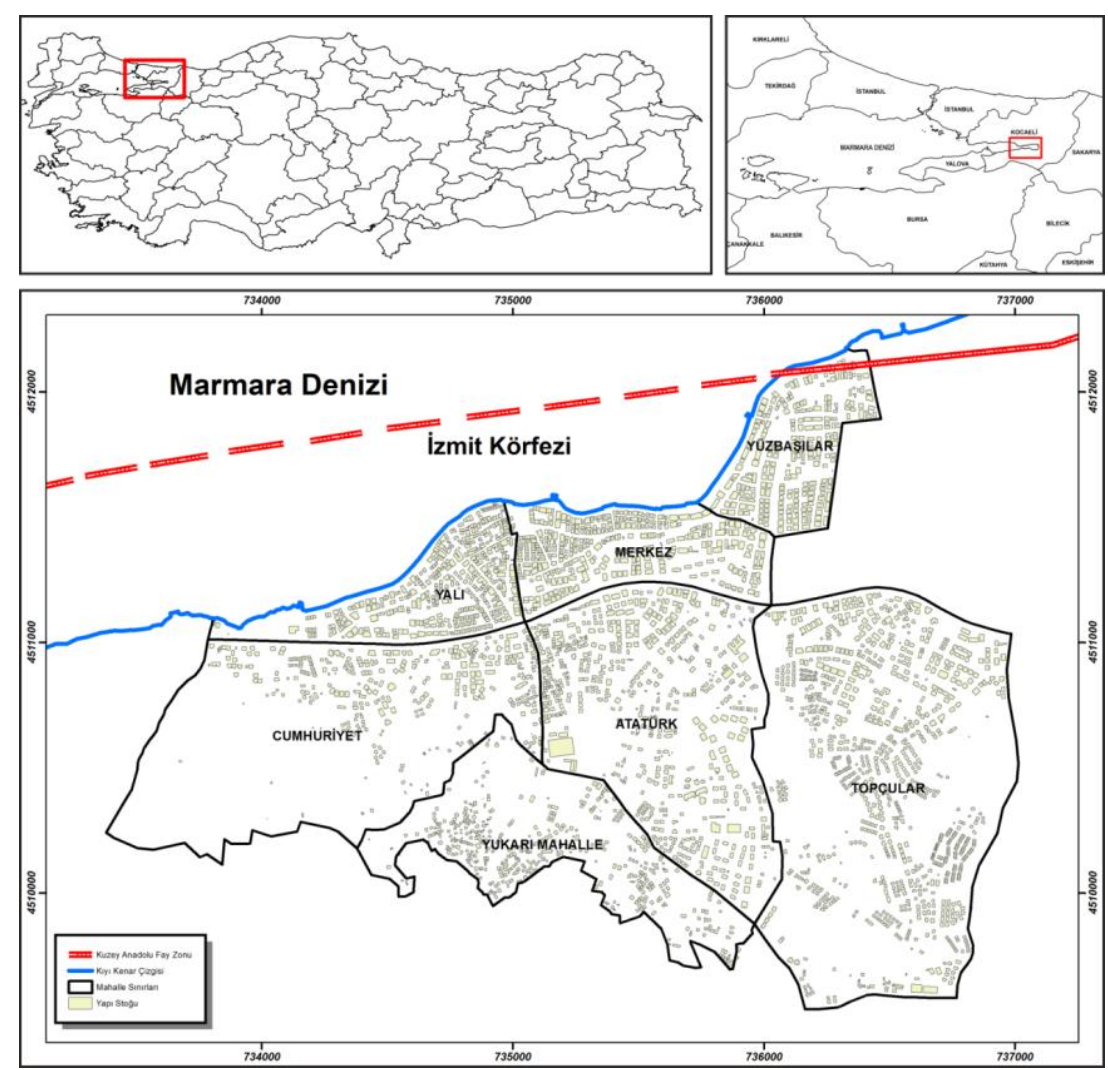

Şekil 1: Çalışma alanı 


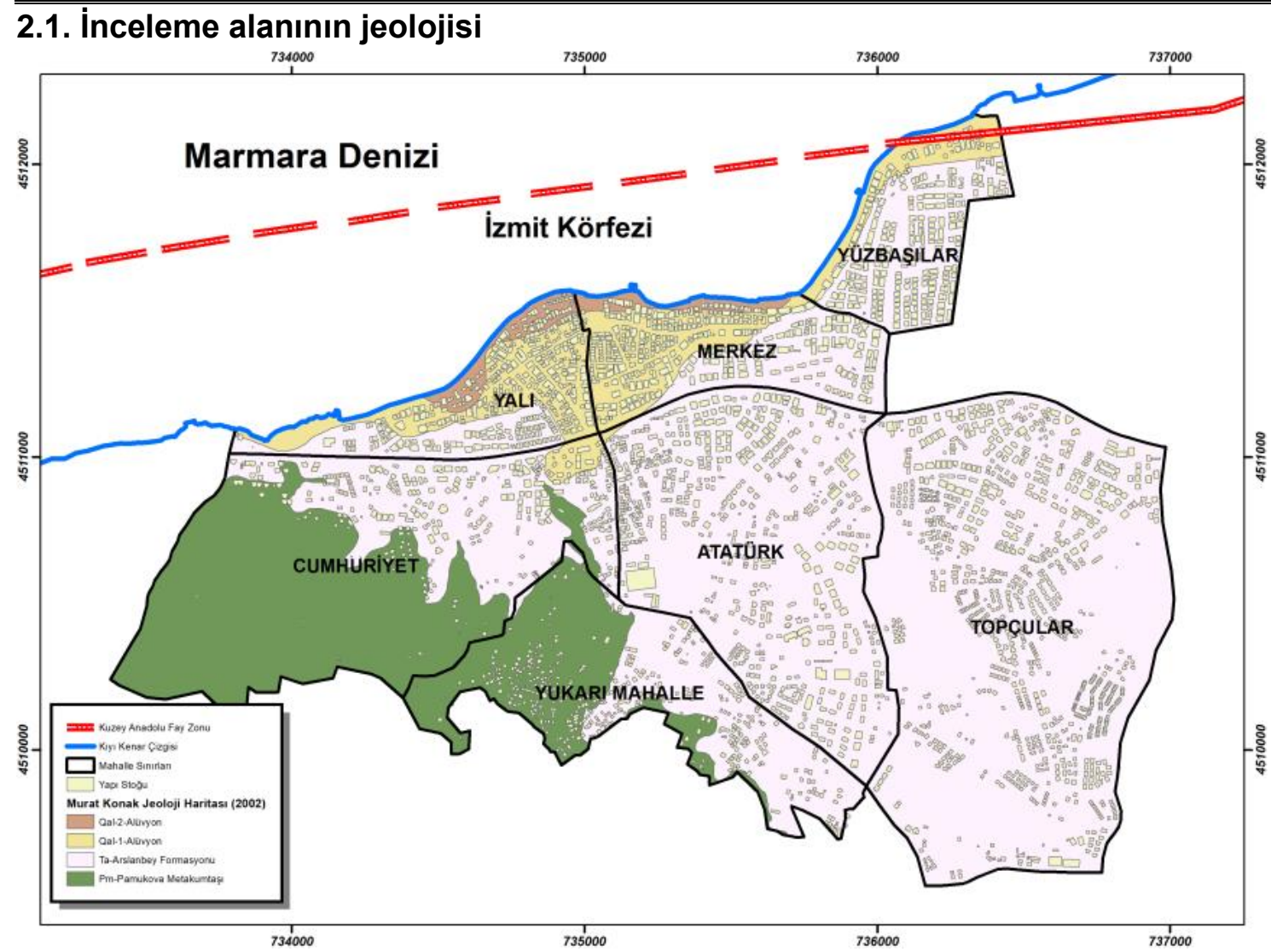

Şekil 2: Konak (2002) tarafından hazırlanan jeoloji haritası

\subsection{1. İznik metamorfik topluluğu}

İnceleme alanımızdaki metamorfik temel birimler daha önceki araştırmacılar tarafından İznik metamorfik topluluğu olarak isimlendirmiştir (Yılmaz ve diğ.,1995). Çalışma sahası içerisinde, batı ve güneybatıdaki yüksek kesimlerde yüzeyleyen metamorfikler, metakumtaşımetasilttaşı-şeyl ardalanmasından oluşan metakırıntıı kayalardan meydana gelmektedir. Birim koyu yeşilimsi gri renkli, yer yer belirgin şistoziteli, çok çatlaklı ve parçalıdır. Deformasyonun yoğun olduğu kesimlerde kayalar ilksel dokularını kaybetmiş ve şist haline dönüşmüştür. Metamorfiklerin en üst seviyesini Kristalen kalkerler oluşturmaktadır. Kısmen kompakt kısmen şisti görünüşte, çok çatlaklı gri-kırmızımsı renklerden oluşan kristalen kalkerlerin ayrışmaya maruz kalmış kesimlerde, beyaz, açık gri, kirli sarı renkler hakimdir. Inceleme alanının güneybatısındaki yükseltileri oluştururlar.

Önder ve Göncüoğlu (1989), yaş verecek bir bulguya rastlamasalar da, birimin Alt Jura ile örtülü olan Karakaya Kompleksi ile deneştirilebileceğini belirtirler. Yılmaz ve diğ. (1995), metamorfik serisinin en üstünde yer alan hafif başkalaşmış pelajik kireçtaşı-çamurtaşıradiolarit kayalarının Üst Kretase yaşında olduğunu belirtirler. Ayrıca, serinin en üzerinde yer alan Kampaniyen-Maastirhtiyen çökel kayalarına göre metamorfizma muhtemelen Turonian sonrası, geç Kampaniyen öncesi arasındaki zaman diliminde gerçekleşmiştir (Yılmaz ve diğ., 1995).

\subsubsection{Aslanbey formasyonu}

Çalışma alanının kuzeyini kaplayan Pliyosen çökelleri Göncüoğlu ve diğ. (1986) tarafından Arslanbey Formasyonu olarak adlandırılmıştır. Birim inceleme alanı içerisinde genel olarak sarımsı kahve renkli olan az tutturulmuş çakıl, kum, silt, kil, çamurtaşı ve marn 
aradalanmasından oluşur. Bazı seviyelerde çok düzenli ve ince-orta katmanlıdır. Birim içerisindeki bağlayıcı madde genellikle kil olup, birim az tutturulmuş ve gevşektir. Çalışma sahasının batı-güneybatısındaki Paleozoyik yaşlı İznik Metamorfik topluluğu ile diskordanslı olarak görülür. Akartuna (1968) Armutlu yarımadasının batısındaki Sarmasiyen çökelleri üzerinde uyumsuz olarak yer alan bu birimlerin Ponsiyen - Pliyosen çökelleri olduğunu belirtilir. Arslanbey formasyonu bölgenin şekillenmesinde önemli rol oynayan Kuzey Anadolu Fayı'na bağlı hareketlerden etkilenmiştir.

\subsubsection{Alüvyon}

İnceleme alanı içerisinde kıyı ve akarsu ortamlarında gözlemlenen birim, yüksek rakımlı güney kesimlerden aşınıp parçalanan jeolojik birimlerin kuzeyde düşük topoğrafik eğime sahip alanlara taşınmaları ve birikimleri sonucu oluşmuştur. Kuvaterner yaşlı birim, kil, silt, kum, çakıl boyutunda tanelerden oluşan tutturulmamış çökeller halindedir.

Tablo 1. Yapıların jeolojik birimler üzerindeki dağılımları

\begin{tabular}{|llc|}
\hline \multicolumn{1}{|c}{ Jeolojik Birim } & \multicolumn{1}{c|}{ Açıklama } & Bina Sayısı \\
\hline Pm & Pamukova Metakumtaşı: qem=2 kg/cm2 & 234 \\
\hline Qal-1 & $\begin{array}{l}\text { Alüvyon: Az çakıllı, Kil, Siltli Kil, Kum, Katı veya Sıkı Zemin, } \\
\text { qem=0,75-1,25 kg/cm2 }\end{array}$ & 489 \\
\hline Qal-2 & $\begin{array}{l}\text { Genç Alüvyon: Kil, Silt, Kum, Çakıl yer yer Kavkı Parçalı, Orta } \\
\text { Katı veya Orta Sıkı Zemin, qem= 0,5-0,75 kg/cm2 }\end{array}$ & 135 \\
\hline Ta & $\begin{array}{l}\text { Arslanbey Formasyonu: Az tutturulmuş Çakıl, Kum, Silt, Kil, } \\
\text { Karbonatlı Kil, Katı veya Sıkı Zemin, qem=0,75-2 kg/cm2 }\end{array}$ & 2554 \\
\hline
\end{tabular}

\section{MATERYAL VE YÖNTEM}

Çalışmanın başlangıcında belediyelerden elde edilen haritalar incelendiğinde, bu verilerle çalışma alanındaki yapı sayısının birbirinden farklı olduğu tespit edilmiştir. Gölcük Belediyesi'nden elde edilen haritalara göre 2450 yapıya ulaşılırken Kocaeli Büyükşehir Belediyesi'nden elde edilen verilere göre Ocak 2013 tarihinde 3456 adet yapı çalışmaya dahil edilmiştir. Hava fotoğrafları ve alan analizlerinden elde edilen güncel veriye bağlı olarak Kocaeli Büyükşehir Belediye Başkanlığı'ndan alınan verilerin kullanılmasına karar verilmiştir.

Yerel yönetimlerden, özel kuruluşlar, kurum ve üniversitelerden elde edilen veriler CBS ortamında yapıya ait öznitelik değerlerine eklenmiştir. Sonrasında hesaplanan risk değerleri ile yapının durumu ortaya konmuştur. Çalışma alanındaki tüm yapılar için, Nüfus Vatandaşlık Genel Müdürlüğü (NVI)'nden Kasım 2014 tarihinde alınan demografik bilgiler yine CBS ortamında yapının nitelik bilgileri ile eşleştirilmiştir. Tüm bu bu birleştirme ve sentez işlemlerine imkan veren ve mekânsal referanslı veri işleyebilen CBS afet yönetimi çalışmalarında kaçınılmaz bir gereklilik haline gelmiştir.

CBS veri alt yapısı oluşturulduktan sonra, yerbilimleri raporları, arazi gözlemleri ve 17 Ağustos 1999 depremi sonrasında çalışma alanında elde edilmiş bilgiler doğrultusunda 28 adet veri belirlenmiştir. CBS ortamına aktarılan 28 adet veri üzerinde yapıya deprem anında hasar verme potansiyeline göre değerlendirme yapılmış ve 7 adet veri tehlike analizinde kullanılacak olan ağırlıklarının hesaplanması için seçilmiştir. Seçilen 7 veri üzerinde Analitik Hiyerarşik Süreç (AHS) uygulanarak Tehlike analizinde kullanılacak olan ağırlık değerleri elde edilmiştir. AHS sonucunda elde edilen ağırlıklar, çalışma alanındaki her bir yapının öznitelik değeri olarak CBS ortamına aktarılmıştır. Bu ağırlıklar veri gruplarının alt nicelik değerleri ile çarpılarak söz konusu kritere ait risk değerleri hesaplanmıştır. Bu risk 
Değirmendere'nin CBS Tabanlı Deprem Risk ve Erişebilirlik Analizi

The GIS-Based Earthquake Risk and Accessibility Analysis of Değirmendere

değerlerinin toplamından sonuç tehlike analizi değeri elde edilmiştir.

Elde edilen risk analizi sonuçlarından;

- Nüfus Vatandaşlık Genel Müdürlüğü'nden alınan nüfus bilgileri ile birleştirilerek riskli yapı ve nüfus ilişkisi,

- Yol ağı verileri ile yapılan erişebilirlik analizi ile stratejik yapıların ve açık yeşil alanların afet sonrası kullanılabilme durumları otaya konmuştur.

\section{1. Çalışma Alanı Yapı Stoğu ve CBS Ortamındaki Özellikleri}

Çalışma başlangıcında alan ile ilgili veriler toplanmıştır. Toplanan verilerin karşılaştırmaları yapıldığında, kurumların hepsinde farklı yapı adetleri ve özellikleri görülmüştür. Gölcük Belediyesi'nden elde edilen verilere göre 2450 yapıya ulaşılırken Kocaeli Büyükşehir Belediyesi'nden elde edilen verilere göre 3456 adet yapıya ulaşımıştır. Hava fotoğrafları ve alan analizlerinden elde edilen güncel veriye bağlı olarak Kocaeli Büyükşehir Belediye Başkanlığı'ndan alınan verilerin kullanılmasına karar verilmiştir. Bu verilerde Nüfus Vatandaşlık İşleri Genel Müdürlüğü (NVI)'nün kullandığı "Adres No" tanımlaması gibi bir özellik olmadığından Kocaeli Büyükşehir Belediyesi CBS Şube Müdürlüğü'nün ürettiği "KBB_BINAID" (Kocaeli Büyükşehir Belediyesi Bina ID Numarası) polygon tanımlaması için kullanılmıştır.

"KBB_BINAID" kullanımının, veri girişi sırasında karışıklığı önlemek açısından oldukça önemli bir yeri vardır. "KBB_BINAID" yi kullanmak yerel yönetimler ile veri paylaşımı ve ortak dili konuşmak açısından da önemlidir. NVi ile görüşülerek alan ile ilgili poligon bazlı demografik yapıya ait bilgiler elde edilmiştir. "Adres No" bilgisi de bu veriler içinde yer almaktadır. "Adres No" ve "KBB_BINAID" çakıştırılması yapılarak tüm veriler aynı anda iki ID tanımlaması ile eşleştirilmiştir.

3456 adet yapı polygonu tanımlanmış olan CBS katmanı incelendiğinde, bazı polygonların kullanım fonksiyonlarının, spor alanlarını veya farklı nitelikteki alanları gösterdiği görülmüştür. Sonuç kısmında yapılacak olan, tehlike analizi hesaplaması çalışması öncesinde alandaki toplanma alanları ve bunların yapılara olan uzaklıklarının veri gurubuna girilmesi ile bu polygonların niteliklerine daha fazla değer kazandırmıştır.

\subsection{Kullanılan Veriler}

Çalışmada deprem tehlike analizinde kullanılacak veri gurupları, akademisyenler ve özel sektör temsilcileri tarafından belirlenmiştir (Tablo 2). Belirlenen bu veriler, bölgede yapılmış teknik rapor, tez, proje veya diğer akademik çalışmalardan elde edilmeye çalışılmıştır. Veri tabanına eklenen kriterlere ait değerler, çalışma alanında yapılmış olan rapor ve diğer akademik çalışmalar araştııılarak Tehlike Analizi değerlendirmesinde kullanılmak üzere CBS ortamına aktarılmıştır (Bülent Kiper Jeoteknik, 2000; Belirti Mühendislik, 2000; Belirti Mühendislik, 2000; ABM Mühendislik, 2001; Bülent Kiper Jeoteknik, 2002; Konak, 2002; Sismak Mühendislik, 2005; AB Zemin Yapı Analizleri, 2009; Yeryapı Mühendislik, 2009; ABM Mühendislik, 2010; ABM Mühendislik, 2010; ABM Mühendislik, 2010; ARSM Jeoteknik, 2011; ARSM Jeoteknik, 2011; Sismotek, 2011; Gürsu Sismik, 2011; Taştan Mühendislik, 2011; Proteknik, 2011; ABM Mühendislik, 2011; Özalaybey et. all., 2011; Taştan Mühendislik, 2012; ABM Mühendislik, 2012; Taştan Mühendislik, 2012; ABM Mühendislik, 2012). 
Tablo 2. Yapı tehlike analizinde kullanılan veriler ve açıklamaları

\begin{tabular}{|c|c|c|}
\hline Sira & Yerel Zemin Koşulları ve Deprem Etkisi & Açıklama \\
\hline 1. & Binanın Faya Olan Uzaklığı & Metre veya km \\
\hline 2. & $\begin{array}{l}\text { Binanın Faya Göre Asal Eksen Doğrultusu } \\
\text { Faya Dik } \\
\text { Faya Paralel } \\
\text { Diğer }\end{array}$ & $\begin{array}{l}1 \text { faya dik } \\
2 \text { faya paralel } \\
3 \text { diğer }\end{array}$ \\
\hline 3. & Dere Yatağına Uzaklık & Metre veya km \\
\hline 4. & Yer altı suyu seviyesi & Metre \\
\hline 5. & Ana kaya derinliği & (Özalaybey ve diğ., 2008) \\
\hline 6. & Kıvam durumu & $\begin{array}{l}1 \text { Çok yumuşak } \\
2 \text { Yumuşak } \\
3 \text { Sıkı } \\
4 \text { Sert } \\
5 \text { Çok sert }\end{array}$ \\
\hline 7. & VP hızı & 2. tabaka $P$ dalga hızı \\
\hline 8. & VS hızı & 2. tabaka S dalga hızı \\
\hline 9. & $\mathrm{~V}_{\mathrm{s}(30)}$ & İlk 30 metredeki S dalga Hızı \\
\hline 10. & Kohezyon (C) & \\
\hline 11. & İçsel Sürtünme Açısı (Ø) & \\
\hline 12. & Jeolojik Formasyon Etkisi & $\begin{array}{l}\text { Bölgesel jeoloji haritalarından } \\
\text { girilecek }\end{array}$ \\
\hline 13. & RQD & Kaya zeminler için \\
\hline & Poisson Oranı & $\begin{array}{l}\text { S dalgasından elastik } \\
\text { parametreler }\end{array}$ \\
\hline 14. & Bulk Modülü & $\begin{array}{l}\text { S dalgasından elastik } \\
\text { parametreler }\end{array}$ \\
\hline 15. & Kayma Modülü & $\begin{array}{l}\text { S dalgasından elastik } \\
\text { parametreler }\end{array}$ \\
\hline 16. & $\mathrm{~T}_{0}$ (Zemin Hakim Titreşim Peryodu) (Sismik verilerden) & Sismik verilerden \\
\hline 17. & Yatak katsayısı & Sismik verilerden \\
\hline 18. & Sıvılaşma & $\begin{array}{l}1 \text { Var } \\
2 \text { Yok }\end{array}$ \\
\hline 19. & Taşıma gücü & Sondaj verilerinden \\
\hline 20. & Zemin emniyet gerilmesi & Sismik verilerden \\
\hline 21. & Zemin Büyütmesi & Mikrotremor verilerinden \\
\hline 22. & Zemin Hakim Titreşim Peryodu & Mikrotremor verilerinden \\
\hline 23. & Zemin Sınıflaması & Mikrotremor verilerinden \\
\hline 24. & $\begin{array}{l}\text { Yapılmış çalışmalardan AFAD terminolojisine göre } \\
\text { yerleşim uygunluk durumu (ÖA, UA, UOA, AJE, vb) }\end{array}$ & Eski raporlardan \\
\hline 25. & İvme değeri & \\
\hline 26. & 1999 depremindeki hasar durumu & $\begin{array}{l}1999 \text { depremi Bayındırlık gözlem } \\
\text { raporlarından } \\
1 \text { hasarsız } \\
2 \text { hafif hasar } \\
3 \text { orta hasar } \\
4 \text { ağır hasar } \\
5 \text { yıkılmış? }\end{array}$ \\
\hline 27. & Eğim/tepe- yamaç etkisi (\%30dan fazla olma durumu) & \% cinsinden eğim verisi \\
\hline
\end{tabular}

\subsection{Demografik dağılım}

Afet riski, hasar, zarar, kayıp ve olumsuz sonuçlara yol açma potansiyeli taşıyan bir olayın, doğurabileceği maddi kayıpların toplamıdır. Risk sözcüğü, belirli bir tehlikenin, gelecekte belirli bir zaman suresi içerisinde meydana gelmesi halinde, insan, insan yerleşmeleri ve çevre üzerinde, bu unsurların zarar veya hasar görebilirlikleri ile orantılı olarak yol açacağı kayıpların olasılığını ifade eder.

Riskten veya kayıp olasılığından bahsedebilmek için, belirli büyüklükte bir tehlike veya olayın var olması, bu olaydan etkilenebilecek değerlerin (insan, yapı, v.b.) bulunması ve bu 
Değirmendere'nin CBS Tabanlı Deprem Risk ve Erişebilirlik Analizi

The GIS-Based Earthquake Risk and Accessibility Analysis of Değirmendere

değerlerin tehlike veya olaydan etkilenme oranları veya zarar görebilirliklerinin tahmin edilebilmesi gerekmektedir.

Afet riski matematiksel olarak: Risk $=$ Tehlike $\times$ Değer (Etkilenebilecek unsurlar) $\mathrm{x}$ Zarar görebilirlik (Etkilenme oranı) olarak ifade edilebilir.

Dolayısıyla riski belirleyen önemli faktör tehlikeli bina sayılarının belirlenmesi olduğu gibi aynı zamanda bu binalarda yaşayan insan sayısı da diğer önemli konudur. Değirmendere bütününde NVI'den alınan ayrıntılı nüfus verilerinin (Şekil 3) binalar ile ilişkilendirilmesi suretiyle elde edilen sonuçlar, kaç kişinin olası bir deprem afeti durumunda etkilenebileceğini göstermekte ve riski tarif etmektedir.

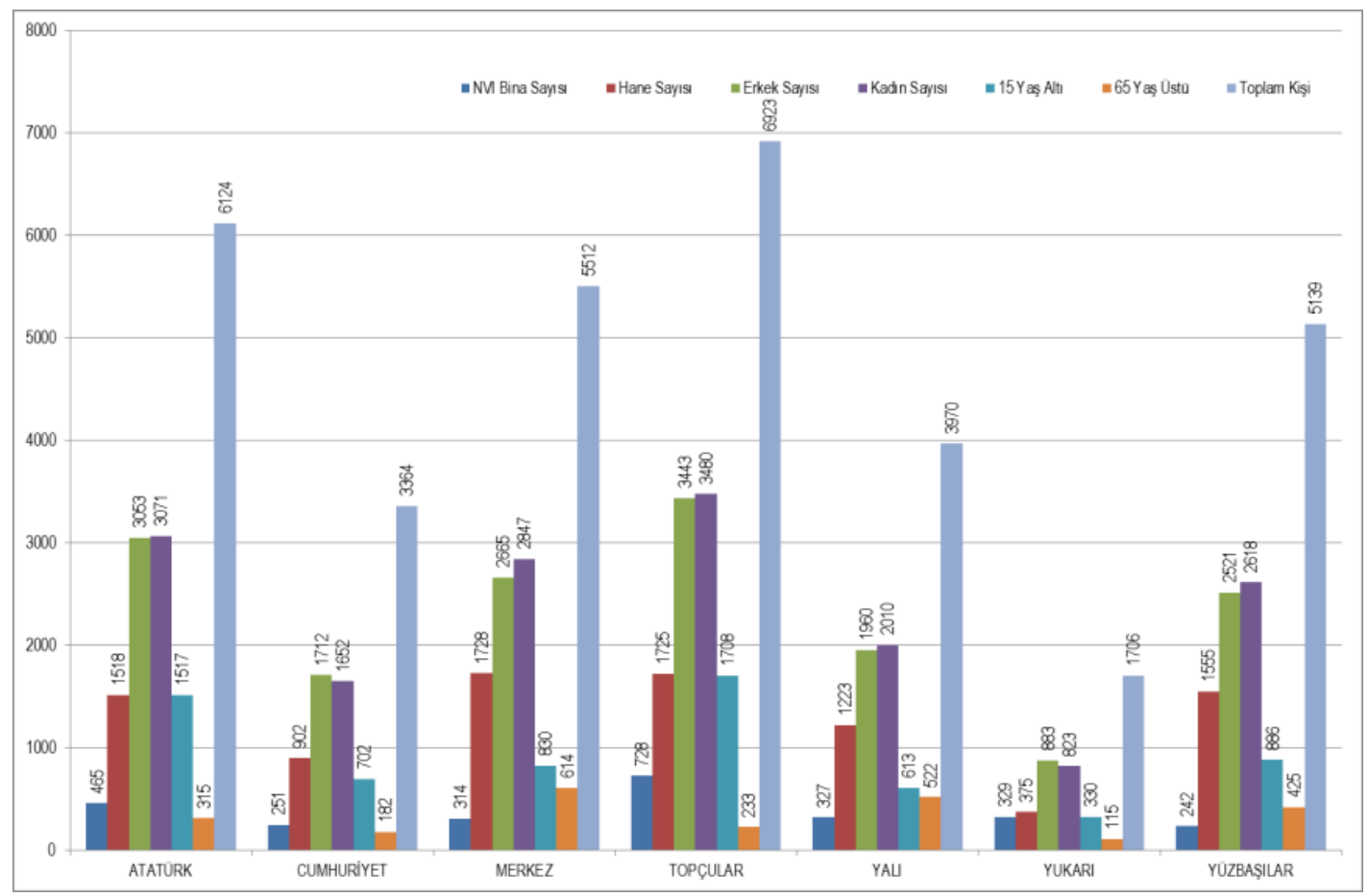

Şekil 3: Yapılardaki demografik dağılım

Tablo 3: Konut sayıları ve demografik dağılım

\begin{tabular}{|llllllll|}
\hline Mahalle & Toplam Bina & Hane Sayısı & Toplam Nüfus & Kadın & Erkek & K15 & B65 \\
\hline Atatürk & 465 & 1.518 & 6.124 & 3.053 & 3.071 & 1.517 & 315 \\
\hline Cumhuriyet & 251 & 902 & 3.364 & 1.712 & 1.652 & 702 & 182 \\
\hline Merkez & 314 & 1.728 & 5.512 & 2.665 & 2.847 & 830 & 614 \\
\hline Topçular & 728 & 1.725 & 6.923 & 3.443 & 3.480 & 1.708 & 233 \\
\hline Yalı & 327 & 1.223 & 3.970 & 1.960 & 2.010 & 613 & 522 \\
\hline Yukarı & 329 & 375 & 1.706 & 883 & 823 & 330 & 115 \\
\hline Yüzbaşılar & 242 & 1.555 & 5.139 & 2.521 & 2.618 & 886 & 425 \\
\hline Toplam & 2.656 & 9.026 & 32.738 & 16.237 & 16.501 & 6.586 & 2.406 \\
\hline
\end{tabular}

Tablo 3, çalışma alanında bulunan yapı, hane ve nüfus dağılımını göstermektedir. Değirmendere'nin nüfus dağılımı incelendiğinde kırılgan nüfus oranı \%27,47 olarak görülmektedir.

\subsection{Analitik Hiyerarşik Süreç (AHS)}

Tehlike analizi haritasında kullanılacak olan kriterlerin seçimi kadar bu kriterlere uygulanacak ağırlıklandırma işlemi de önemlidir. Çalışma alanı için seçilen kriterlerin güvenilir ve tehlikeyi 
tam yansıtabilmesi gereklidir. Bu zorunluluklar, verilerin ağırlıklandırılmasında kullanılacak yöntemi de öne çıkarmaktadır.

Kullanılacak yöntem;

- Çalışmamızdaki gibi büyük ölçekli problemleri derleyebilecek esnek bir model içermeli,

- Çok sayıda kriterin problemin çözümüne dahil edilebilmeli,

- Problemin çözümünde objektifliği sağlayabilmeli,

- Ortaya çıkan değerler, CBS ortamında kolay uygulanabilmeli,

- Geniş uygulama alanına sahip olmalıdır.

$\mathrm{Bu}$ özellikleri ile öne çıkan, çok kriterli karar verme yöntemi olan Analitik Hiyerarşik Süreç (AHS) yöntemi, çalışmamızda kullanıımıştır.

\subsubsection{Tehlike Analizi Saptanmasında Kullanılacak Verilerin Ağırlıklandırılması}

CBS altyapısı oluşturulurken, çalışma alanından bağımsız olarak, depremde etkisi olduğu düşünülen veriler akademisyenler ve konusunda uzman kişilere sorularak listelenmiştir. 28 adet veriden oluşan bu listeden (Tablo 2); bölge özelinde, yapıya deprem anında hasar verme potansiyelleri göre değerlendirilmiş ve 7 adet veri seçilmiştir (Tablo 4). AHS yöntemi ile ağırlıklandırılma yapılacak olan bu veriler Tablo 4'de görülmektedir.

Tablo 4: Ağırlıklandırmaları hesaplanacak olan veri gurubu

\begin{tabular}{|ll|}
\hline Sıra & Yerbilimleri Faktörleri \\
\hline 1. & Binanın Faya Olan Uzaklığı (FU) \\
\hline 2. & Binanın Faya Göre Asal Eksen Doğrultusu (Faya Dik, Faya Paralel,Diğer) (FD) \\
\hline 3. & Yer altı suyu seviyesi (YAS) \\
\hline 4. & $\mathrm{V}_{\mathrm{s}(30)}(\mathrm{VS})$ \\
\hline 5. & Jeolojik Formasyon Etkisi (JFE) \\
\hline 6. & Zemin Sınıflaması (Mikrotremor verilerinden) (ZS) \\
\hline 7. & Eğim/ tepe- yamaç etkisi (\%30dan fazla olma durumu) (E) \\
\hline
\end{tabular}

Analitik Hiyerarşik Süreç (AHS), ilk olarak 1968 yılında Myers ve Alpert ikilisi tarafından ortaya atılmış ve Saaty 1977 'de bir model olarak geliştirilerek karar verme problemlerinin çözümünde kullanılabilir hale getirilmiştir (Yaralıoğlu, 2004).

AHS, karmaşık karar problemlerinde, karar alternatif ve kriterlerine göreceli önem değerleri verilerek yönetsel karar mekanizmasının çalıştırılması esasına dayanan bir karar verme işlemidir (Timor, 2011).

Farklı kaynaklarda değişik adımlara bölünmüş olan AHS aşamaları Yaralıoğlu 2004 ve Timor 2011'e göre derlenerek çalışmada uygulanmıştır.

AHS yönteminin akış şeması Şekil 4'de görülmektedir. 


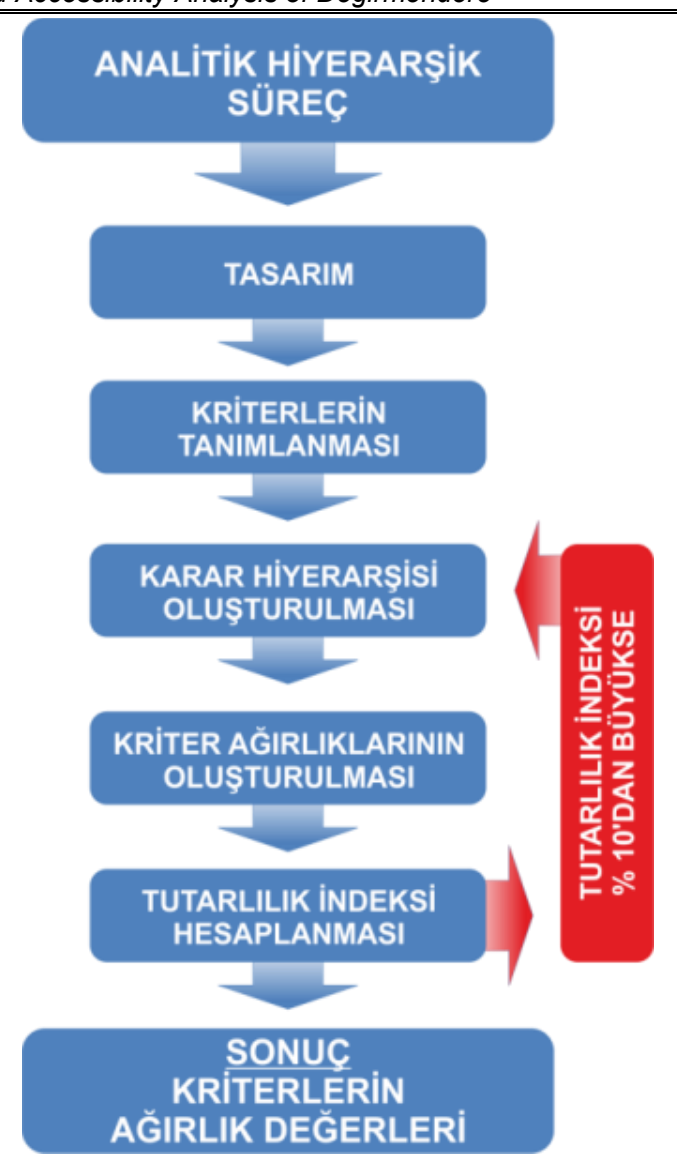

Şekil 4: AHS yöntemi akış şeması

AHS 4 ana aşamada tamamlanmaktadır.

1. Karar verme problemi tanımlanması,

2. Faktörler arası karşılaştırma matrisi oluşturulması,

3. Faktörlerin yüzde önem dağılımları belirlenmesi,

4. Faktör kıyaslamalarında tutarlılık ölçümü.

Bu aşamaların sonucunda tutarlılık değeri \%10'un altında ise yapılan değerlendirmenin tutarlı olduğu, elde edilen ağırlık değerlerinin de kullanılabilir olduğu ortaya çıkmaktadır.

Tablo 4'teki verilere AHS uygulaması sonucunda Tablo 5'teki ağırlık değerlerine ulaşılmıştır.

Tablo 5. Tehlike analizinde kullanılacak olan kriterlerin ağırlıkları

\begin{tabular}{|llc|}
\hline Sıra & Yerbilimleri Faktörleri & $\begin{array}{c}\text { Yer Bilimleri Tehlike Analizi } \\
\text { Katsayıları (\%) }\end{array}$ \\
\hline 1. & Jeolojik Formasyon Etkisi & 29,68 \\
\hline 2. & Zemin Sınıflaması (Mikrotremor verilerinden) & 24,89 \\
\hline 3. & Yer altı suyu seviyesi & 15,84 \\
\hline 4. & V $_{\mathrm{S}(30)}$ & 10,79 \\
\hline 5. & Binanın Faya Olan Uzaklığı & 9,39 \\
\hline 6. & Binanın Faya Göre Asal Eksen Doğrultusu & 4,81 \\
\hline 7. & Eğim/ tepe- yamaç etkisi & 4,58 \\
\hline
\end{tabular}

\section{TOPLAM TEHLIKE HARITALARI}

AHS sonucunda elde edilen Tablo 5'teki ağırlık değerleri, oluşturulan CBS altyapısında her bir yapının öznitelik değerlerine eklenmiştir. Kriterlerin dağılımı ve öznitelik değerlerinin toplamından elde edilmiş olan toplam tehlike haritası Şekil 5 görülmektedir. 


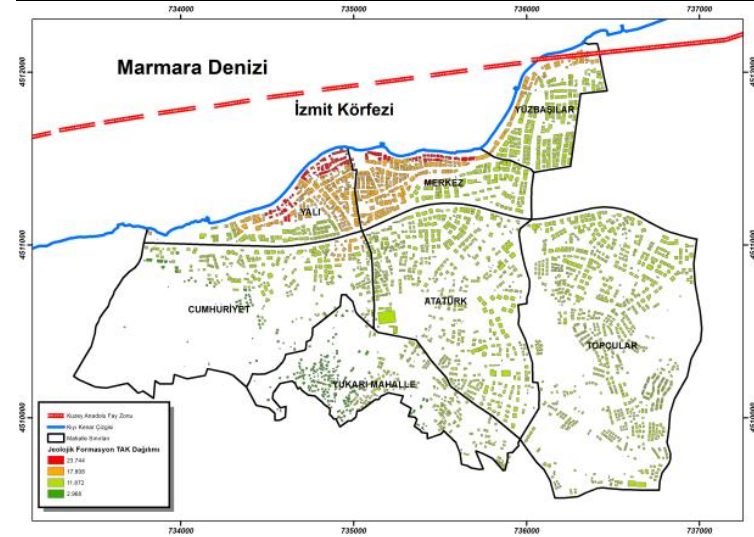

Şekil 5.1: Jeolojik formasyon TAK değerleri dağılımı

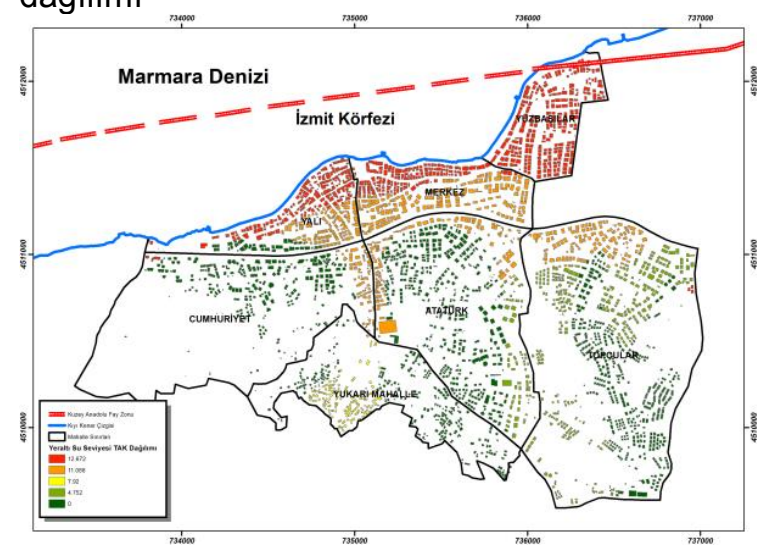

Şekil 5.3: Yeraltı su seviyesi ${ }^{n+m}$ TAK değerleri dağılımı

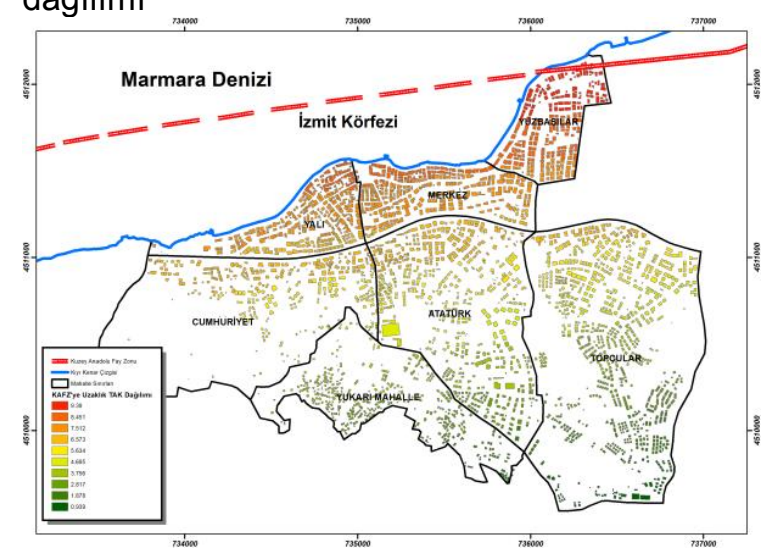

Şekil 5.5: KAFZ'ye uzaklık TAK değerleri dağııımı

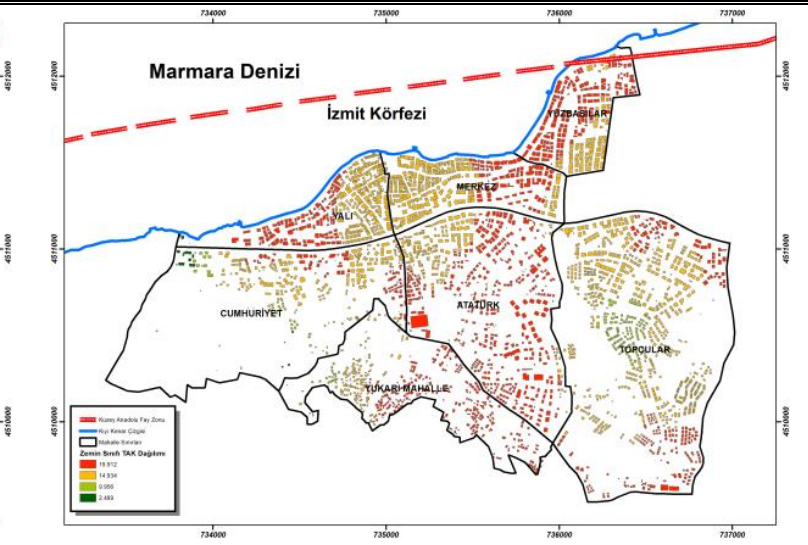

Şekil 5.2: Mikrotremor zemin sınıf। TAK değerleri dağııımı

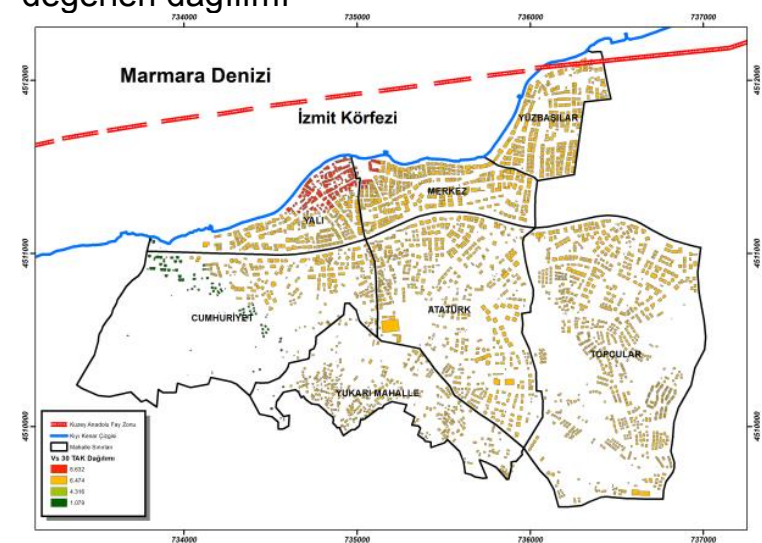

Şekil 5.4: $\stackrel{\mathrm{V}}{\mathrm{S}(30)}_{\mathrm{m})}$ TAK değerleri dağıı

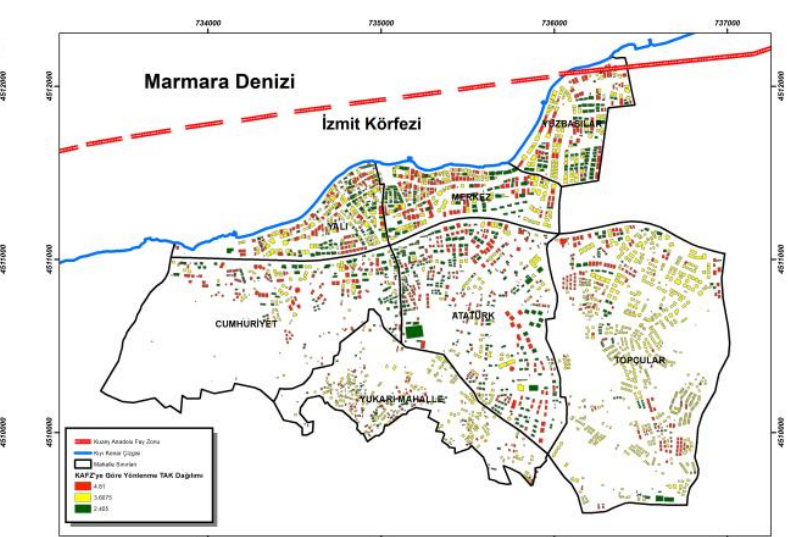

Şekil 5.6: KAFZ'ye göre yönlenme TAK değerleri dağıımı

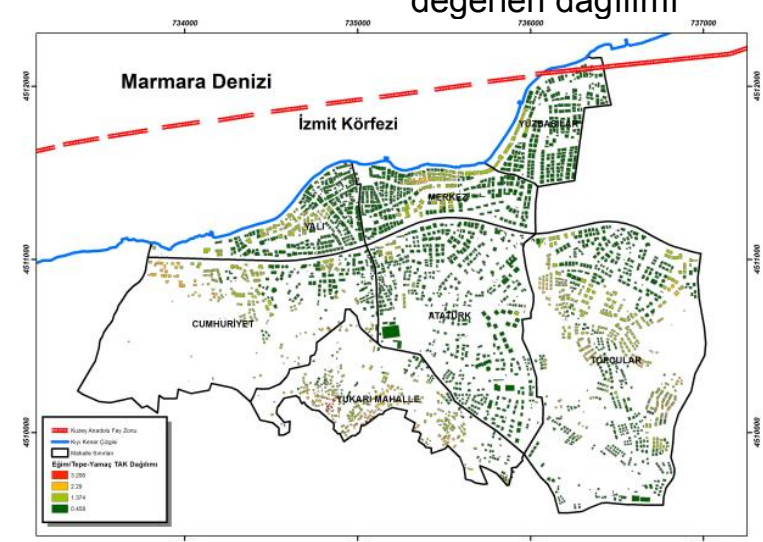

Şekil 5.7. Eğ 
Değirmendere'nin CBS Tabanlı Deprem Risk ve Erişebilirlik Analizi

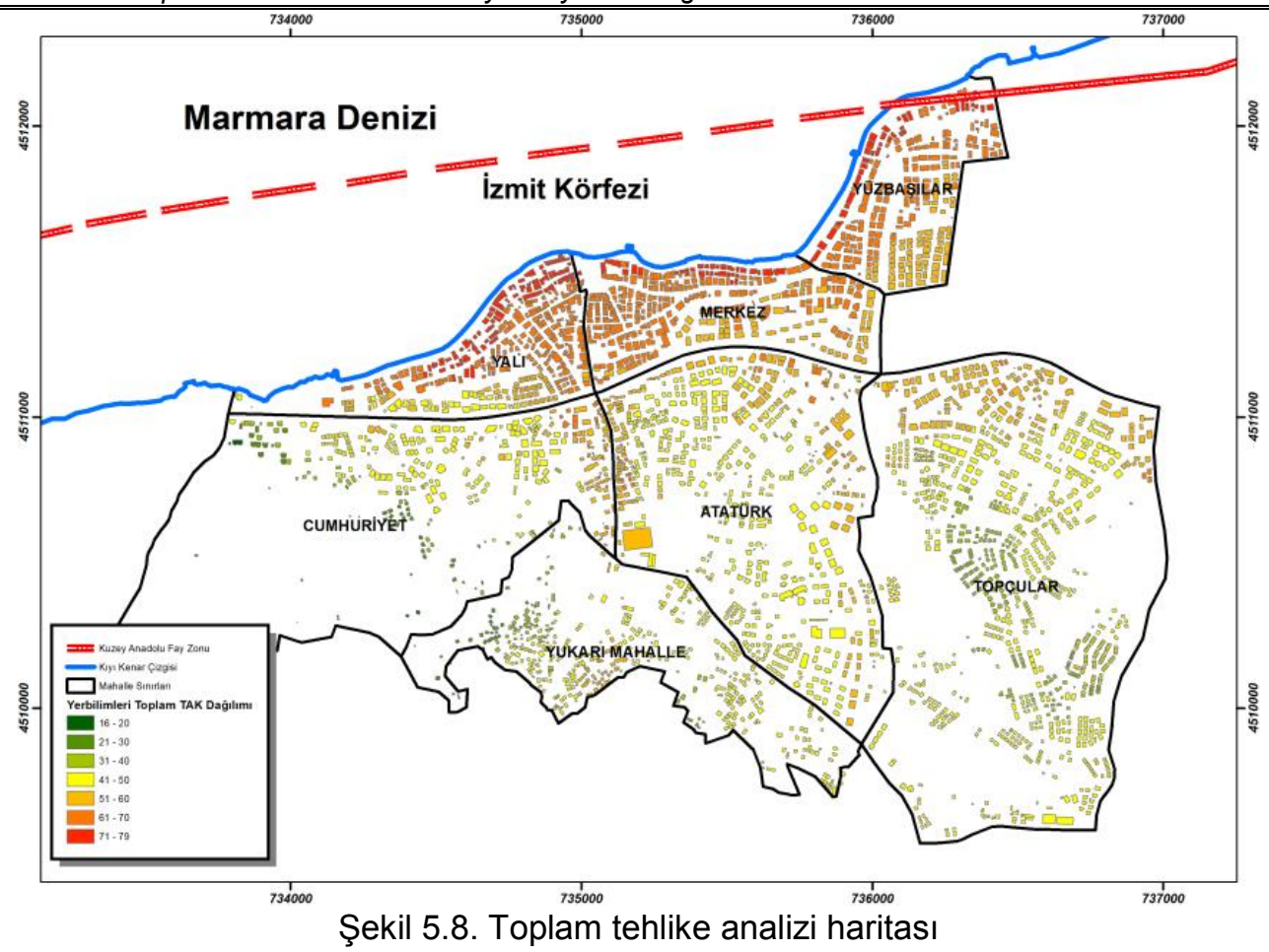

Çalışma alanı için elde edilen veri guruplarının değerlendirilmesi sonucunda, her bir veri gurubunun tehlike analizi sonuçlarının toplamından alanın risk dağılımı elde edilmiştir (Şekil 5.8). Elde edilen risk dağılımının sınıflanması sonucunda en fazla yapının \%41-50 risk aralığında bulunduğu görülmektedir (Tablo 5).

\section{SONUÇ VE ÖNERILER}

Çalışma alanı, doğal afetler ve özellikle de deprem riski altındadır. Bu riskten kaynaklanacak zararları kontrol edebilmek için öncelikle riski ve riski oluşturan sebepleri bilmek gerekir. Çalışmada Değirmendere bölgesi için deprem tehlike analizi yapılarak bu risk değerleri yapı özelinde belirlenmiş ve bu yapılardaki etkilenecek nüfus ve nüfusun özellikleri ortaya konmuştur (Tablo 5-6).

Çalışma alanında bulunan 3456 adet yapının yerbilimleri verileri ile tehlike analizleri yapılmıştır. Elde edilen sonuçlara göre 1502 adet yapı yüksek riskli olarak belirlenmiştir. Değirmendere'nin toplam nüfusunun \%58,10'u, ayrıca; kırılgan nüfus kapsamında olan 5172 kişi yine bu yüksek riskli yapılarda yaşamaktadır.

Tablo 5: Toplam TAK değerleri ve riske maruz kalan nüfus dağılımı

\begin{tabular}{|cccccccccc|}
\hline Sınıf & $\begin{array}{c}\text { Yapı } \\
\text { Adedi }\end{array}$ & $\begin{array}{c}\text { Yapı } \\
\text { Oranı } \\
(\%)\end{array}$ & Erkek & Kadın & B65 & K15 & $\begin{array}{c}\text { Kişi } \\
\text { Sayısı }\end{array}$ & $\begin{array}{c}\text { Kişi } \\
\text { Oranı } \\
(\%)\end{array}$ & Hane \\
\hline $\mathbf{1 6 - 2 0 , 0 0}$ & 5 & 0,14 & 13 & 9 & 2 & 1 & 22 & 0,07 & 8 \\
\hline $\mathbf{2 1 - 3 0 , 0 0}$ & 73 & 2,11 & 175 & 176 & 15 & 68 & 351 & 1,10 & 93 \\
\hline $\mathbf{3 1 - 4 0 , 0 0}$ & 278 & 8,04 & 472 & 472 & 45 & 172 & 944 & 2,95 & 260 \\
\hline $\mathbf{4 1 - 5 0 , 0 0}$ & 1598 & 46,24 & 5867 & 5827 & 565 & 2779 & 11694 & 36,51 & 2901 \\
\hline $\mathbf{5 1 - 6 0 , 0 0}$ & 646 & 18,69 & 4401 & 4467 & 567 & 1793 & 8868 & 27,69 & 2449 \\
\hline $\mathbf{6 1 - 7 0 , 0 0}$ & 658 & 19,04 & 4088 & 4312 & 900 & 1381 & 8400 & 26,22 & 2546 \\
\hline $\mathbf{7 1 - 7 8 , 6 8}$ & 198 & 5,73 & 855 & 897 & 290 & 241 & 1752 & 5,47 & 576 \\
\hline TOPLAM & $\mathbf{3 4 5 6}$ & $\mathbf{1 0 0}$ & $\mathbf{1 5 8 7 1}$ & $\mathbf{1 6 1 6 0}$ & $\mathbf{2 3 8 4}$ & $\mathbf{6 4 3 5}$ & $\mathbf{3 2 0 3 1}$ & $\mathbf{1 0 0}$ & $\mathbf{8 8 3 3}$ \\
\hline
\end{tabular}




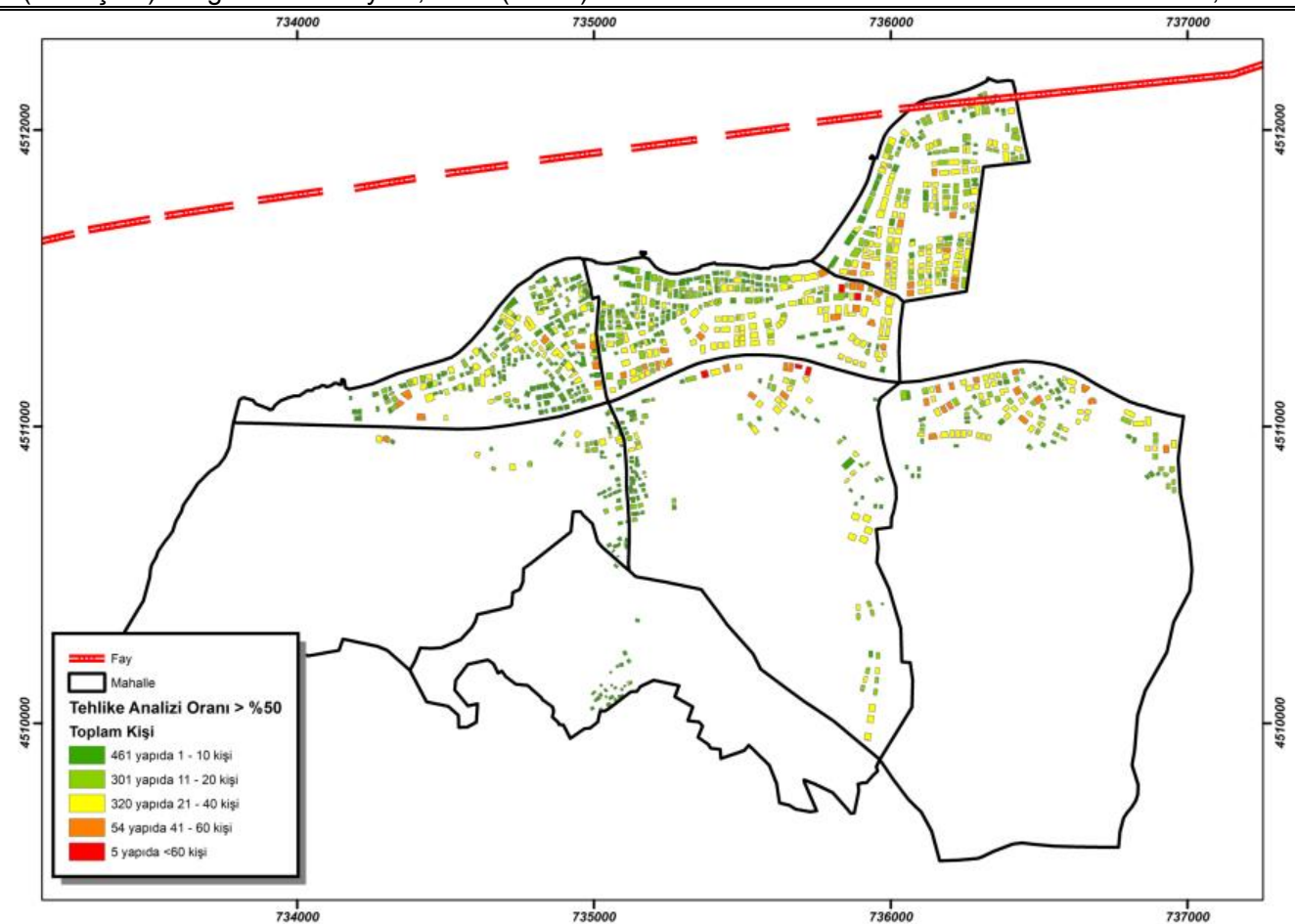

Şekil 6: Tehlike analizi yüksek yapılardaki nüfus dağııımı

Tablo 6. Hasargörebilirliği yüksek yapılardaki nüfus dağııımı

\begin{tabular}{|cccccccccc|}
\hline Sınıf & $\begin{array}{c}\text { Yapı } \\
\text { Adedi }\end{array}$ & $\begin{array}{c}\text { Yapı } \\
\text { Adedi } \\
(\%)\end{array}$ & Erkek & Kadın & B65 & K15 & $\begin{array}{c}\text { Kişi } \\
\text { Sayısı }\end{array}$ & $\begin{array}{c}\text { Kişi } \\
\text { Sayısı } \\
(\%)\end{array}$ & Hane \\
\hline $\mathbf{1 6 - 5 0 , 0 0}$ & 1954 & 56,53 & 6527 & 6484 & 627 & 3020 & 13011 & 40,62 & 3262 \\
\hline $\mathbf{5 1 - 7 8 , 6 8}$ & 1502 & 43,47 & 9344 & 9676 & 1757 & 3415 & 19020 & 59,38 & 5571 \\
\hline TOPLAM & $\mathbf{3 4 5 6}$ & $\mathbf{1 0 0}$ & $\mathbf{1 5 8 7 1}$ & $\mathbf{1 6 1 6 0}$ & $\mathbf{2 3 8 4}$ & $\mathbf{6 4 3 5}$ & $\mathbf{3 2 0 3 1}$ & $\mathbf{1 0 0}$ & $\mathbf{8 8 3 3}$ \\
\hline
\end{tabular}

Toplam nüfusun \%59,38'lik kısmı riski yüksek yapılarda konaklamaktadır. Riskin yoğun olduğu yerler aynı zamanda yapılaşmanın da yoğun olduğu alanlardır. Müdahale ve kurtarma çalışmalarında zorluk yaşanması beklenmektedir.

Bölgedeki yol ağı kullanılarak yapılmış olan Network analizi sonucunda, afet sonrası toplanma alanı olarak kullanılabilecek olan, stratejik yapılar ve açık-yeşil alanlara erişilebilirlik haritaları elde edilmiştir (Şekil 7-8).

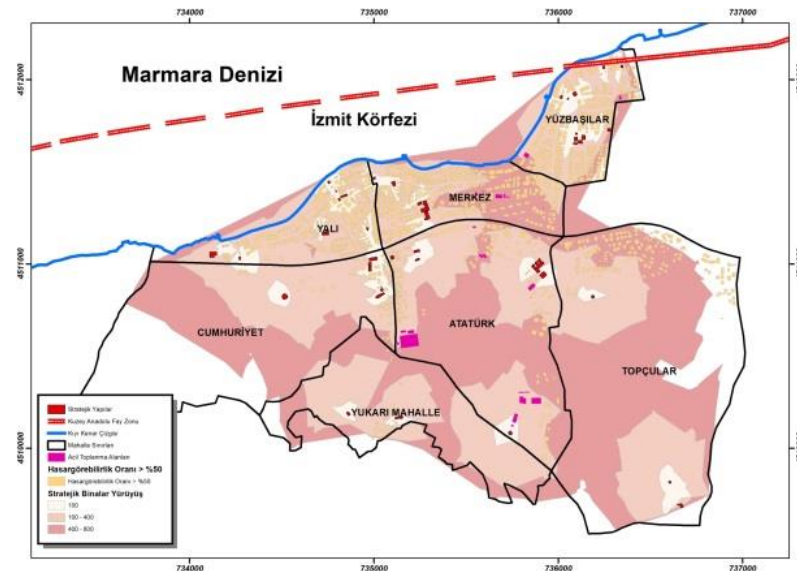

Şekil 7: Stratejik yapılar erişebilirlik analizi

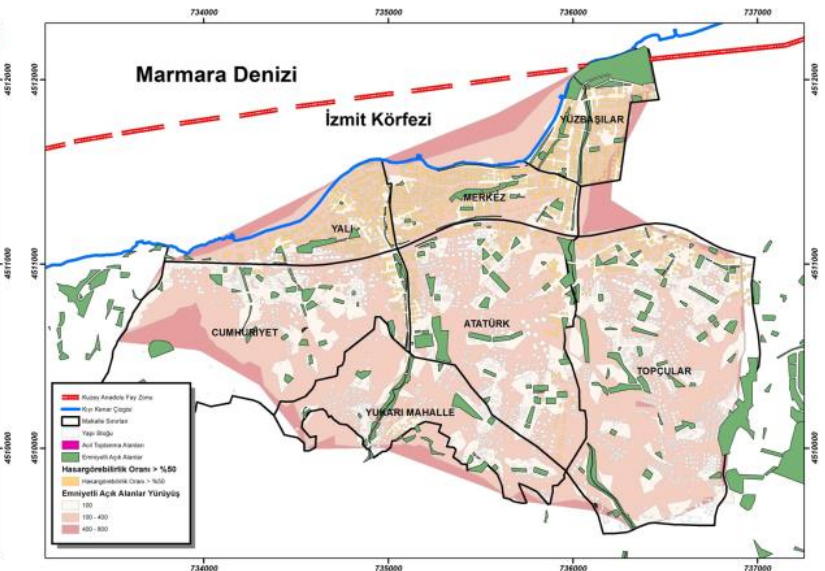

Şekil 8: Açık-yeşil alanlar erişebilirlik analizi 
Değirmendere'nin CBS Tabanlı Deprem Risk ve Erişebilirlik Analizi

The GIS-Based Earthquake Risk and Accessibility Analysis of Değirmendere

Erişilebilirlik analiz sonuçları olası bir deprem sonrasında mevcut yol ağı üzerinden afet sonrası kullanılması düşünülen yapılara erişim iç açıcı görünmemektedir. Çalışma alanımız eki bir yerleşim bölgesidir. Bu ve benzeri alanlarda tekrar planlama yapılması, erişim ağının daha kullanılabilir hale getirilmesi zor olabilir. Ancak yapılacak küçük planlama değişiklikleri ile afet sonrası karşılaşılacak zorlular hafifletilebilecektir.

Yapılaşmaya açılacak yeni yerleşim yerlerinde de olası afet durumunda yaplara erişimi rahatlatacak uygulamalar can ve mal kayıplarını azaltacağı gibi toplumun yeniden afet öncesi duruma gelmesini kolaylaştıracaktır.

\section{TEŞEKKÜR}

Çalışma, Ocak 2015 yılında tamamlanan, 112M421 proje no'lu, "Kocaeli- GölcükDeğirmendere Beldesi Kentsel Afet Risk Yönetimine Dair Tehlike Analizinin Saptanması Projesi” başlıklı TÜBITAK projesi üzerinden hazırlanmıştır. Desteğinden dolayı TÜBITAK'a Teşekkür ederiz. Bu projede emeği geçen tüm çalışanlara teşekkürü bir borç biliriz.

\section{KAYNAKLAR}

1. AB Zemin ve Yapı Analizleri Ltd. Şti., Gölcük Belediyesi Gelişim Alanları (G23C01C3A, G23C01C3C, G23C01C3D, G23C01C4B) İlave İmar Planına Esas Jeolojik-Jeoteknik Etüt Raporu, AB Zemin ve Yapı Analizleri Ltd. Şti., 2009.

2. ABM Müh. Ltd. Şti., Kocaeli İli Gölcük Belediyesi Değirmendere Mahallesi G23C01D2C Pafta 1296 Parseldeki Hüseyin Levent'e Ait Sahanın Revize İmar Planına Esas Jeolojik-Jeoteknik Etüt Raporu, ABM Müh. Ltd. Şti., 2010.

3. ABM Müh. Ltd. Şti., Kocaeli Illi Gölcük Belediyesi Değirmendere Mahallesi G23C01C1D Pafta 5603 Parseldeki İbrahim Türkmenoğlu'na Ait Sahanın Revize İmar Planına Esas JeolojikJeoteknik Etüt Raporu, ABM Müh. Ltd. Şti., 2010.

4. ABM Müh. Ltd. Şti., Kocaeli İli Gölcük Belediyesi Değirmendere Mahallesi G23C01C2A Pafta 4257 Parseldeki Mehmet Şen'e Ait Sahanın Revize İmar Planına Esas Jeolojik-Jeoteknik Etüt Raporu, ABM Müh. Ltd. Şti., 2010.

5. ABM Müh. Ltd. Şti., Kocaeli Illi Gölcük Belediyesi Değirmendere Mahallesi G23C01D2C Pafta 1296 Parseldeki Hüseyin Levent'e Ait Sahanın Revize İmar Planına Esas Jeolojik-Jeoteknik Etüt Raporu, ABM Müh. Ltd. Şti., 2010.

6. ABM Müh. Ltd. Şti., Kocaeli Illi Gölcük Belediyesi Örcün Mevkii Abdurrahman Kesgin ve Nurettin Olhan Sahası, 1/1000 Ölçekli İmar Planına Esas Jeolojik-Jeoteknik Etüt Raporu, ABM Müh. Ltd. Şti., 2012.

7. ABM Müh. Ltd. Şti., Kocaeli İli Gölcük İlçesi Değirmendere Belediyesi Seyhun Karademir ve Hiss.'na Ait G23C01C1A Pafta 5755 Parselde Bulunan Arsanın Jeoteknik Zemin Etüt Raporu, ABM Müh. Ltd. Şti., 2001.

8. ABM Müh. Ltd. Şti., Kocaeli İli Gölcük İlçesi Değirmendere Belediyesi Seyhun Karademir ve Hiss.'na Ait G23C01C1A Pafta 5755 Parselde Bulunan Arsanın Jeoteknik Zemin Etüt Raporu, 2001.

9. ABM Müh. Ltd. Şti., Kocaeli İli Gölcük İlçesi Gölcük Belediyesi Değirmendere Mevkii G23C01C2D, G23C01C1C, G23C01C2C, G23C01C3A, G23C01C4B Paftaları Revize İmar Planına Esas Jeolojik-Jeoteknik Etüt Raporu, ABM Müh. Ltd. Şti., 2011.

10. ABM Müh. Ltd. Şti., Kocaeli İli Gölcük İlçesi Gölcük Belediyesi Örcün Mevkii Yakup Olhan ve Hiss.'na Ait G23C02D4A, G23C02D1D Paftaları 475 Ada 5 Parselde Bulunan Arsanın 1/1000 Ölçekli Revize İmar Planına Esas Jeolojik-Jeoteknik Etüt Raporu, ABM Müh. Ltd. Şti., 2012.

11. Acerer S., Afet Konutları Sorunu ve Deprem Örneğinde İncelenmesi, Yüksek Lisans Tezi, İstanbul Teknik Üniversitesi, Fen Bilimleri Enstitüsü, İstanbul, 1999, 100598.

12. Akartuna M., Armutlu Yarımadasının Jeolojisi, İstanbul Üniversitesi Fen Fak. Mono., 1968, 20, 120.

13. Aksaraylı M., Coğrafi Bilgi Sistemi Tabanlı Acil Afet Yönetim Sistemi: İzmir İli Uygulaması, Doktora Tezi, Dokuz Eylül Üniversitesi, Sosyal Bilimler Enstitüsü, İzmir, 2005, 162266. 
14. ARSM Jeoteknik Müh. Ltd. Şti, Kocaeli İli Değirmendere İlçesi G23C01C1C Nolu pafta, 215 Ada 2 Nolu Parsele Ait İmar Planı Revizyonuna Esas Jeolojik-Jeoteknik Etüt Raporu, ARSM Jeoteknik Müh. Ltd. Şti, 2011.

15. ARSM Jeoteknik Müh. Ltd. Şti, Kocaeli İli Değirmendere İlçesi G23C01D2C Nolu pafta, 4900 Nolu Parsele Ait İmar Planı Revizyonuna Esas Jeolojik-Jeoteknik Etüt Raporu, ARSM Jeoteknik Müh. Ltd. Şti, 2011.

16. Belirti Müh.-Dan. A.Ş., Gölcük Belediyesi Kuzey Gölcük Alanının İmara Esas JeolojikJeoteknik Etüt Raporu, Belirti Müh.-Dan. A.Ş., 2000.

17. Belirti Müh.-Dan. A.Ş., Halıdere Belediyesi 138 Hektarlık Alanının İmara Esas JeolojikJeofizik-Jeoteknik Etüt Raporu, Belirti Müh.-Dan. A.Ş., 2000.

18. Bülent Kiper Jeoteknik Müh. Ltd. Şti., Değirmendere (Kocaeli) İmar Adaları Ayrıntılı Jeolojik Jeoteknik Etüt Raporu, Bülent Kiper Jeoteknik Müh. Ltd. Şti., 2002.

19. Bülent Kiper Jeoteknik Müh. Ltd. Şti., Değirmendere (Kocaeli) Yerleşim Amaçlı Temel Sondajları ve Jeolojik-Jeoteknik- İnceleme Raporu, Bülent Kiper Jeoteknik Müh. Ltd. Şti., 2000.

20. Güler H. H., Zarar Azaltmanın Temel İlkeleri, Afet Zararlarını Azaltmanın Temel İlkeleri, İsmat Matbaacılık, Ankara, 35-51, 2008.

21. Konak M., Gölcük-Değirmendere (Kocaeli) Bölgesinde 17 Ağustos 1999 Depreminde Oluşan Yapı Hasarlarına Zemin Özelliklerinin Etkisi, Yüksek Lisans Tezi, Kocaeli Üniversitesi, Fen Bilimleri Enstitüsü, Kocaeli, 2002, 128199.

22. Önder F., Göncüoğlu M. C., Armutlu Yarımadasında (Batı Pontidler) Üst Triyas Konodontları, MTA Dergisi, 1989, 109, 147-152.

23. Özalaybey S., Zor E., Tapırdamaz M.C., Tarancıoğlu A., Özalaybey S. Ç., Erkan B., Karaaslan A., Alpaslan E., Ergin M., Ergintav S., Tan E., Kocaeli İli için Zemin Sınıflaması ve Sismik Tehlike Değerlendirme Projesi, TÜBiTAK, 5057105, 190, 2008.

24. Proteknik Uluslararası Müh. Ltd. Şti., Kocaeli İli Değirmendere İlçesi G23C01C3B, G23C01C3A, G23C01C2C, G23C01C2D Paftalarında Kalan 281 Ada 3, 4, 5 Nolu Parsellerin İmar Planı Revizyonuna Esas Jeolojik-Jeoteknik Etüt Raporu, Proteknik Uluslararası Müh. Ltd. Şti., 2011.

25. Sis-Mak Müh. Ltd. Şti., Kocaeli Büyükşehir Belediyesi Değirmendere Yapı Yasaklı Alanlarda Yapılacak Olan Jeolojik-Jeofizik-Jeoteknik Etüt İşi, Sis-Mak Müh. Ltd. Şti., 2005.

26. Sismotek Müşv. İnş. Müh. Ltd. Şti., Kocaeli İli, Gölcük İlçesi, Donanma Komutanlığı Sorumluluğunda Bulunan, Yaklaşık 187.5 Hektarlık Arazinin, İmar Planına Esas JeolojikJeoteknik Etüt Raporunun Hazırlanması (G23C01C2B, G23C01C2C, G23C01B3C, G23C02A4D, G23C02D1A, G23C02D1D, G23C02A4C, G23C02D1C, G23C02D1B, G23C02A3D, G23C02D2D, G23C02D2A, G23C02A3C, G23C02D2B, G23C02C1A nolu paftalarda), Sismotek Müşv. İnş. Müh. Ltd. Şti., 2011.

27. Taştan Mühendislik Hizmetleri, Kocaeli İli Gölcük İlçesi Değirmendere Mahallesi G23C01C1B Pafta, 388 Parselde Bulunan Ersin Çetin'e ait Arsanın İmar Planına Esas Jeolojik-Jeoteknik Etüt Raporu, Taştan Mühendislik Hizmetleri, 2012.

28. Taştan Mühendislik Hizmetleri, Kocaeli İli Gölcük İlçesi G23C01C1A Pafta, 3341 Parselde Bulunan Yılmaz Özmen'e ait Arsanın Revize İmar Planına Esas Jeolojik-Jeoteknik Etüt Raporu, Taştan Mühendislik Hizmetleri, 2011.

29. Taştan Mühendislik Hizmetleri, Kocaeli İli Gölcük İlçesi G23C02D4A Pafta, 495 Ada, 12 Parselde Bulunan Şule Arslan'a ait Arsanın Revize İmar Planına Esas Jeolojik-Jeoteknik Etüt Raporu, Taştan Mühendislik Hizmetleri, 2012.

30. Timor M., Analitik Hiyerarşi Prosesi, Türkmen Kitapevi, İstanbul, 2011.

31. URL-1: http://udim.koeri.boun.edu.tr/ (Ziyaret Tarihi: 15 Nisan 2015).

32. Yaralıoğlu K., Uygulamada Karar Destek Yöntemleri, İlkem Ofset, İzmir, 2004.

33. Yeryapı Müh. Ltd. Şti., Kocaeli İli Gölcük İlçesi Değirmendere Belediyesi G23C01C1B Pafta 3530 Parselde Bulunan Gökhan-Berna Erişir'e Ait Arsanın İmar Planına Esas JeolojikJeoteknik Etüt Raporu, Yeryapı Müh. Ltd. Şti., 2009.

34. Yılmaz Y., Genç Ş. C., Yiğitbaş E., Bozcu M., Yılmaz K., Geological evolution of the late Mesozoic continental margin of Northwestern Anatolia, Tectonophysics, 1995, 243, 155-171. 